\title{
Larvicidal potential of Cyathea species against Culex quinquefasciatus
}

\author{
Janakiraman Narayanan ${ }^{1}$, Johnson Marimuthu alias Antonysamy ${ }^{1 *}$ \\ ${ }^{1}$ Centre for Plant Biotechnology, Department of Botany, St. Xavier’s College (Autonomous), Palayamkottai - 627 002, Tamil Nadu, India \\ Received: Jul 1, 2016, Revised: Sep 24, 2016, Accepted: Mar 4, 2017
}

\begin{abstract}
Resistance to insecticides has persuaded researchers to find new methods to control Culex quinquefasciatus proliferation. Plants may be a source of alternative agents for mosquito control due to ever-growing insecticide resistance in mosquito vectors and environmental imbalance caused by synthetic insecticides. The present study was intended to study the larvicidal activity of selected Cyathea species against the filarial vector Culex quinquefasciatus. Larvicidal potential of different extracts were evaluated and larval mortality were recorded. The larvae were more sensitive to ethanolic extracts of studied three Cyathea species when compared to other extracts. Acetone, chloroform and petroleum ether extracts were considered to be less effective. The $\mathrm{LC}_{50}$ values of different extracts ranged from 320.72 to $657.03 \mu \mathrm{g} / \mathrm{ml}$. The results exhibited that the tested three Cyathea species showed concentration dependent potential larvicidal effects and also provide an indication of possible bioactive properties.
\end{abstract}

Keywords: Tree ferns, culex quinquefasciatus, larvicidal

Pharm Biomed Res 2017; 3(1): 48-51

\section{Introduction}

Vector-borne diseases are the major cause of morbidity in most of the tropical and subtropical countries. Mosquitoes are one of the important vectors responsible for the spread of several diseases viz., malaria, filariasis, dengue fever and Japanese encephalitis. Culex sp. is the most abundant mosquito species in urban areas. It is crucial to manage Culex population so that people can be protected from various mosquito borne diseases. These diseases can be controlled by targeting the causative parasites and pathogens. The chemical control was one of the most extensively used conventional methods for controlling mosquito borne diseases since chemical pesticides are relatively inexpensive and usually produces immediate control. Generally, the chemical control is carried out by the indoor residual spraying of insecticides such as temephos, insect growth regulators such as diflubenzuron and methoprene, which are still the most effective. Insecticide applications against the target species are facing a serious threat due to the development of resistance to chemical insecticides (1). Numerous studies have been carried out to identify safer mosquito control agents and to reduce environmental and human health concern $(2,3)$. An approach to obtain efficient, safe and selective insecticides is the study of natural products obtained from plants (4).In the world flora, next to angiosperms, pteridophytes occupy an important position in which many extant species were recorded (5). Pteridophytes are conspicuous and gorgeous elements of biodiversity which occurs in various kinds of habitats ranging from sea level to mountain top and tropical to subpolar regions (6). With reference to Cyathea species, Janakiraman and Johnson (7) studied the presence of phenolics, flavonoids, tannins, cardiac glycosides, terpenoids, steroids, saponins and alkaloids in $C$. nilgirensis, $C$. gigantea and C. crinita. Janakiraman and Johnson (8) determined the functional constituents of $C$. nilgirensis, $C$. gigantea and $C$. crinita. using FT-IR. Janakiraman and Johnson (9) studied the antioxidant potentials of $C$. nilgirensis, $C$. gigantea and $C$. crinita. Janakiraman and Johnson (10) revealed the phenolics profile of tree ferns using HPTLC analysis. Janakiraman and Johnson (11) studied the chemical constituents of tree ferns using GCMS analysis. Janakiraman and Johnson (12) confirmed the cytotoxic activity of ethanolic extracts of selected Cyathea species against MCF 7 cell line cultures. Hence, the present study was undertaken to study the larvicidal potential of various extracts of Cyathea nilgirensis Holttum, Cyathea gigantea (Wall. ex. Hook.) Holttum and Cyathea crinita (Hook.) Copel.

\section{Materials and methods \\ Collection of plant materials}

Samples for the present study were collected from different parts of Tamil Nadu, South India. 
C. nilgirensis were harvested in and around Kakkachi stream (1,725 m), Tirunelveli hills ( $8^{\circ} 44^{\prime} \mathrm{N}$ and $\left.77^{\circ} 44^{\prime} \mathrm{E}\right), C$. gigantea from the road sides near Nadugani $(2,637 \mathrm{~m})$, Nilgiris hills ( $11^{\circ} 24^{\prime} \mathrm{N}$ and $76^{\circ} 44^{\prime} \mathrm{E}$ ) and C. crinita from the Anglade Institute of Natural History, Shenbaganur, Kodaikanal (2,195 m), Palni hills ( $10^{\circ} 13^{\prime} \mathrm{N}$ and $\left.77^{\circ} 32^{\prime} \mathrm{E}\right)$, Western Ghats, South India. The specimens were identified based on the "Pteridophyte Flora of the Western Ghats, South India" by Manickam and Irudayaraj (13). Herbarium specimens were deposited in the St. Xavier's College Herbarium (XCH), Palayamkottai for further reference $(C$. nilgirensis - $\mathrm{XCH}$ 25423; C. gigantea - XCH 25422 and C. crinita - XCH 25424).

\section{Preparation of extracts}

The collected species of Cyathea were thoroughly washed with tap water followed by distilled water. They were blotted on the blotting paper and spread out at room temperature in shade to remove the excess water contents. The shade dried plant samples were ground to fine powder using mixer grinder. The powdered materials were stored in refrigerator for further use. Thirty gram of powdered sample was extracted (1:6 ratio) successively with $180 \mathrm{~mL}$ of petroleum ether, chloroform, acetone and ethanol using the Soxhlet extractor for 8-12 $\mathrm{h}$ at a temperature not exceeding the boiling point of the solvent. The extracts were concentrated in a vacuum at $40^{\circ} \mathrm{C}$ using rotary evaporator.

\section{Larvicidal activity}

Culex quinquefasciatus ( $4^{\text {th }}$ instar larvae) was collected from sewages of Tirunelveli district with the help of 'O' type brush. These larvae were brought to the laboratory and transferred to $18 \times 13 \times 4 \mathrm{~cm}$ size enamel trays containing $500 \mathrm{ml}$ of water. It was maintained at $27 \pm 2{ }^{\circ} \mathrm{C}, 75-85 \% \mathrm{RH}$ and $14 \mathrm{~h}$ light and 10 $\mathrm{h}$ dark photoperiod cycles.

Larvicidal activity of different extracts (petroleum ether, chloroform, acetone and ethanol) with varied concentrations of C. nilgirensis, $C$. gigantea and $C$. crinita was evaluated as per the standard method described by WHO (14). Batches of twenty $4^{\text {th }}$ instar larvae of $C$. quinquefasciatus were collected separately and transferred to small disposable cups each containing $200 \mathrm{~mL}$ of water. The appropriate volume of dilution was added in the cups to obtain the desired target dosage (concentrations ranging from $100-500 \mu \mathrm{g} / \mathrm{ml}$ ) starting with the lowest concentration. Five replicates were set up for each concentration and simultaneously a control was maintained. The larval mortality in both treated and control were recorded after $24 \mathrm{~h}$. The standard larvicide Temephos (Abate) was used as positive control. The control mortality was corrected by Abbott's formula (15).

\section{Statistical analysis}

The $\mathrm{LC}_{50}$ value was calculated by Probit analysis (16). The $\mathrm{IC}_{50}$ values of the crude extracts were found using MS-Excel 2007. Correlation analysis between $\mathrm{LC}_{50}$ and $\mathrm{IC}_{50}$ values were calculated using SPSS (Chicago, USA).

\section{Results}

The results of the larvicidal bioassay of crude petroleum ether, chloroform, acetone and ethanolic extracts of $C$. nilgirensis, $C$. gigantea and $C$. crinita against the fourth instar mosquito larvae C. quinquefasciatus were presented in Table 1 . The larvae were more sensitive to ethanolic extracts of studied three Cyathea species when compared to other extracts. Acetone, chloroform and petroleum ether extracts were considered to be less effective. The $\mathrm{LC}_{50}$ values of different extracts ranged from 320.72 to $657.03 \mu \mathrm{g} / \mathrm{ml}$. Among the three different species tested, the highest larval mortality was observed in ethanolic extracts of $C$. crinita with the $\mathrm{LC}_{50}$ value of $320.72 \mu \mathrm{g} / \mathrm{ml}$ followed by $C$. gigantea $(361.07 \mu \mathrm{g} / \mathrm{ml})$ and $C$. nilgirensis $(373.99 \mu \mathrm{g} / \mathrm{ml})$. The positive control Temephos showed $100 \%$ mortality rate at $0.025 \mathrm{mg} / \mathrm{ml}$. The $95 \%$ confidence limits $\mathrm{LC}_{50}$ (LCL-UCL), $\mathrm{LC}_{90}$ and chi-square values were also calculated (Table 1). The Chi-square values for the studied extracts ranged from 0.35 to 7.37 for $C$. quinquefasciatus. Petroleum ether (0.35), chloroform (0.40) and ethanolic extracts (0.36) of $C$. crinita, chloroform (0.54) and acetone (0.38) extracts of $C$. gigantea and ethanolic extracts (0.69) of $C$. nilgirensis showed a strong positive correlation between the extracts and larval mortality (Table 1). The other tested extracts failed to show direct correlation between insect toxicity.

\section{Discussion}

The control of mosquito larvae by chemical substances is not safe at present because of environmental imbalance and insecticide resistance by vectors which leads to deleterious effects. The major drawback with the use of chemical insecticides is that they are non-selective and could be harmful to other organisms in the environment. Hence, an alternative mosquito control method is needed (17). The extracts which are obtained from plant parts have been used as conventional larvicide $(18,19)$. The observed results were also comparable with earlier reports. The fruit extract of Croton caudatus, flower extract of Tiliacora acuminata (20), leaf extract of Typhonium trilobatum (21) and flower extract of Tagetes erecta (22) were found to cause larval mortality against $C$. quinquefasciatus. In the present study, the different extracts of C. nilgirensis, $C$. gigantea and $C$. crinita exhibited a dose dependent activity. The results observed were similar to previous studies which have also reported dose 
Table 1 Larvicidal activity of different Cyathea species against C. quinquefasciatus

\begin{tabular}{|c|c|c|c|c|c|c|c|}
\hline \multirow[t]{2}{*}{ Species } & \multirow[t]{2}{*}{ Extracts } & \multirow{2}{*}{$\begin{array}{c}\mathrm{LC}_{50} \\
(\mu \mathrm{g} / \mathrm{ml})\end{array}$} & \multicolumn{2}{|c|}{ 95\% Confidence Limits } & \multirow{2}{*}{$\begin{array}{c}\mathrm{LC}_{90} \\
(\mu \mathrm{g} / \mathrm{ml})\end{array}$} & \multirow[t]{2}{*}{$\chi^{2}$} & \multirow{2}{*}{$\begin{array}{c}\mathrm{IC}_{50} \\
(\mu \mathrm{g} / \mathrm{ml})\end{array}$} \\
\hline & & & Lower & Upper & & & \\
\hline \multirow{4}{*}{ C.nilgirensis } & Pet. ether & 607.76 & 512.14 & 894.19 & 893.93 & 3.86 & 66.4 \\
\hline & Chloroform & 592.26 & 482.18 & 917.90 & 1078.70 & 2.73 & 52.3 \\
\hline & Acetone & 448.88 & 394.96 & 536.88 & 966.31 & 1.04 & 57.8 \\
\hline & Ethanol & 373.99 & 338.65 & 417.91 & 758.69 & 0.69 & 51.9 \\
\hline \multirow{4}{*}{ C. gigantea } & Pet. ether & 639.92 & 561.76 & 784.12 & 1013.26 & 1.05 & 55.1 \\
\hline & Chloroform & 624.63 & 532.47 & 813.44 & 1151.44 & 0.54 & 51.4 \\
\hline & Acetone & 468.00 & 394.65 & 620.38 & 1175.06 & 0.38 & 141.6 \\
\hline & Ethanol & 361.07 & 317.84 & 416.12 & 848.87 & 2.29 & 64.8 \\
\hline \multirow{4}{*}{ C. crinita } & Pet. ether & 657.03 & 556.55 & 868.54 & 1178.48 & 0.35 & 50.9 \\
\hline & Chloroform & 568.04 & 489.18 & 722.23 & 1103.12 & 0.40 & 51.9 \\
\hline & Acetone & 400.36 & 292.74 & 776.28 & 870.41 & 7.37 & 61.7 \\
\hline & Ethanol & 320.72 & 291.11 & 351.94 & 645.79 & 0.36 & 50.5 \\
\hline
\end{tabular}

dependency of plant extracts against mosquito larvae $(2,3)$. The results The phytochemical studies on the Cyathea species confirmed the various metabolites $(7,8,10,11)$.

Based on the existing phytoconstituents, the mortality rate of the present study showed varied percentage of mortality rate which may due to the occurrence of phytochemicals in the studied tree ferns. showed variation. The results suggest that the presence of several bioactive secondary metabolites may be responsible for the larval toxicity. Screening the tree fern crude extracts against mosquito larvae may pave a pathway to identify potential bioactive compounds to control mosquito that can be further employed as larvicides. Botanical derivatives have drawn attention as potential insect control agents targeting only larval stages in the mosquito control programme in the last three decades (20-22). The results also supported the previous observations on the larvicidal potential of plant extracts. The statistical analysis results of $C$. nilgirensis showed strong positive correlation between $\mathrm{LC}_{50}$ and $\mathrm{IC}_{50}$ values. The other two studied tree ferns failed to show the positive correlation. But all the three species demonstrated a significant relationship between larval mortality and crude extracts. The larvae were particularly more sensitive to ethanolic extracts of Cyathea species when compared to other extracts. It was also due to the presence of more number of phytochemicals in ethanolic extracts which was confirmed by previous researchers $(7,8,10,11)$. The mechanism of action exhibited by the studied Cyathea species may therefore possibly be due to its toxic effects on the larvae.

\section{Conclusion}

The tested three Cyathea species showed concentration dependent potential larvicidal effects.
The results also provide an indication of possible bioactive properties of the tested extracts. Further investigation is needed to find out the active compounds responsible for the larvicidal activity.

\section{Acknowledgement}

The authors are thankful to University Grants Commission; New Delhi for the financial support through the Major Research Project Grant No. 41-416/2012 (SR) dated $16^{\text {th }}$ July, 2012.

\section{Conflict of interest}

The authors declare that they have no conflict of interest.

\section{References}

1. Hamaidia K, Soltani N. Laboratory evaluation of a biorational insecticide, kinoprene, against Culex pipiens larvae: effects on growth and development. Annu Res Rev Biol 2014;4:2263-73.

2. Kaushik R, Saini P. Larvicidal activity of leaf extract of Millingtonia hortensis (Family: Bignoniaceae) against Anopheles stephensi, Culex quinquefasciatus and Aedes aegypti. J Vector Borne Dis 2008;45:66-9.

3. Govindarajan M. Larvicidal efficacy of Ficus benghalensis L. plant leaf extracts against Culex quinquefasciatus Say, Aedes aegypti L. and Anopheles stephensi L. (Diptera: Culicidae). Eur Rev Med Pharmacol Sci 2010;14:107-11.

4. Perez RP, Bujaidas EM, Cadena SR, Jasso MD, Gallaga JP, Miranda AS, et al. Genotoxic and cytotoxic studies of betasitosterol and pteropodine in mouse. J Biomed Biotechnol 2005;3:242-7.

5. Moran RC. Diversity, biogeography and floristics. In: Ranker TA, Haufler CH, editors. Biology and Evolution of Ferns and Lycophytes. Cambridge University Press, Cambridge, 2008. p. 367-94. 
6. Dudani S, RamachandraTV. Pteridophytes of Western Ghats. First Indian Biodiversity Congress; 2010. p. 156.

7. Janakiraman N, Johnson M. Inter specific variation studies on Cyathea species using phytochemical and fluorescence analysis. Res Rev: J Pharm Toxicol Stud 2015;3:25-31.

8. Janakiraman N, Johnson M. Functional groups of tree ferns (Cyathea) using FTIR: Chemotaxonomic implications. Rom J Biophys 2015;25:131-41.

9. Janakiraman N, Johnson M. In vitro antioxidant properties of natural products isolated from selected species of Cyathea. J Clin Nephrol Res 2015;2:1027.

10. Janakiraman N, Johnson M. HPTLC fingerprint profile (phenolics) of selected Cyathea species from Western Ghats, South India. Chin J Biol 2016;Article ID 6420371.

11. Janakiraman N, Johnson M. GC-MS analysis of ethanolic extracts of Cyathea nilgirensis, $C$. gigantea and C. crinita. Egypt Pharmaceut J 2016;15:43-7.

12. Janakiraman N, Johnson M. Ethanol extracts of selected Cyathea species decreased cell viability and inhibited growth in MCF 7 cell line cultures. J Acupunct Meridian Stud 2016;9:151-5.

13. Manickam VS, Irudayaraj V. Pteridophyte Flora of the Western Ghats, South India. BI Publications Pvt. Ltd., New Delhi; 1992.

14. World Health Organization. Guidelines for laboratory and field testing of mosquito larvicides. WHO/CDS/WHOPES/GCDPP/ 2005.13. Geneva; 2005.
15. Abbott WS. A method of computing the effectiveness of an insecticide. 1925. J Am Mosq Control Assoc 1987;18:265-7.

16. Finney DJ. Probit analysis. London: Cambridge University Press; 1979. p. 68-72.

17. Pavela R. Larvicidal activities of some Euro-Asiatic plants against Culex quinquefasciatus Say (Diptera: Culicidae). Parasitol Res 2009;105:887-92.

18. Das NG, Goswami D, Rabha B. Preliminary evaluation of mosquito larvicidal efficacy of plant extracts. J Vector Borne Dis 2007;44:145-8.

19. Rana IS, Rana AS. Efficacy of essential oils of aromatic plants as larvicide for the management of filarial vector Culex quinquefasciatus (Diptera: Culicidae) with special reference to Foeniculum vulgare. Asian Pac J Trop Dis 2012;2:184-9.

20. Singha S, Banerjee S, Chandra G. Synergistic effect of Croton caudatus (fruits) and Tiliacora acuminata (flowers) extracts against filarial vector Culex quinquefasciatus. Asian Pac J Trop Biomed 2011;1:159-64.

21. Haldar KM, Ghosh P, Chandra G. Evaluation of target specific larvicidal activity of the leaf extract of Typhonium trilobatum against Culex quinquefasciatus Say. Asian Pac J Trop Biomed 2011;1:199-203.

22. Nikkon F, Habib MR, Saud ZA, Karim MR. Tagetes erecta Linn. and its mosquitocidal potency against Culex quinquefasciatus. Asian Pac J Trop Biomed 2011;1:186-8. 